
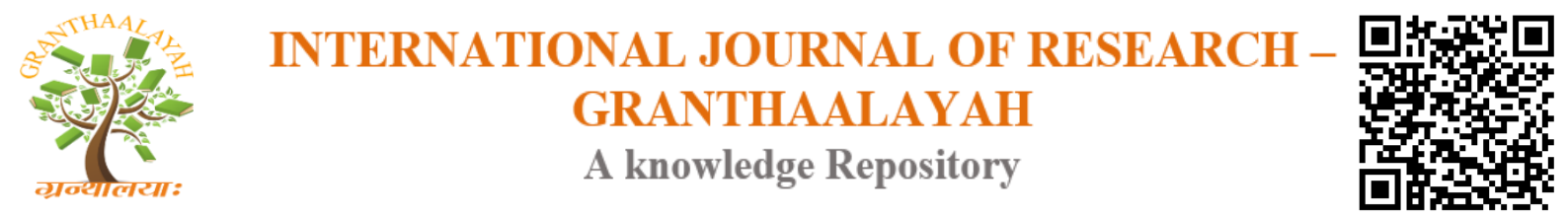

Management

\title{
PROPOSED PLAN OF ACTION AND TRAINING MATRIX FOR ENHANCED RECORDS MANAGEMENT SYSTEM IN THE DEPARTMENT OF EDUCATION MANDAUE CITY DIVISION
}

\author{
Benjamin D, Tiongzon ${ }^{1}$, Adora A. Villaganas ${ }^{2}$, Victor D. Villaganas ${ }^{3}$ \\ ${ }^{1,2,3}$ Graduate School, Cebu Technological University
}

\begin{abstract}
This study assessed the practices of the records management system in the public schools in the Division of Mandaue City on the school year 2012-2013 towards the adoption of an Enhanced School Records Management System. The study further considered the profile of the respondent groups as vital variables which significantly affected the performance of the school records officers or custodians.

Specifically, this study was conceived to look into the level of implementation of the different components of the Records Management System as perceived by the respondents namely; the functions of School Records Office, the Duties and Responsibilities of the Records Officers and the Records Management Operating Procedures which includes the handling of mails and communications, handling of legal documents and administrative issuances, classification guide for filing school management documents, procedure for filing, servicing with files, request for personal information, access to files, records disposal procedure, preservation of records and the retention period or life cycle of records and documents. The responses were identified and analyzed using the weighted mean formula of which the results were collated and tabulated.

Finally, this study aimed to determine the mean difference among the respondent groups' perceptions on the aforementioned prescribed aspects of the School Records Management which was statistically treated through the t-test model. The tally described the results of the respondents' perceptions on the two aspects, the functions of the records office and the duties and responsibilities of records officers, as not significantly related to each other. Both respondents were almost attuned in their perceptions on the abovesaid two aspects. However, a different picture had been seen on the third aspect, operating procedures of Records Management, which established a significant mean difference among the perceptions of the respondent groups.

It is, therefore, in this particular aspect, records management procedure of operations, that the researcher shall devout vast attention in order to enhance and streamline the records management system of public schools in Mandaue City Division.
\end{abstract}

Keywords: Records Management System; RA 9470; Management. 
Cite This Article: Benjamin D, Tiongzon, Adora A. Villaganas, and Victor D. Villaganas. (2017). "PROPOSED PLAN OF ACTION AND TRAINING MATRIX FOR ENHANCED RECORDS MANAGEMENT SYSTEM IN THE DEPARTMENT OF EDUCATION MANDAUE CITY DIVISION." International Journal of Research - Granthaalayah, 5(8), 67-78. https://doi.org/10.29121/granthaalayah.v5.i8.2017.2184.

\section{Introduction}

Greater access to public information and preservation of public documents and records are vital measures to efficient and effective public administration leading towards the attainment of good governance. Likewise, one measure to improve the delivery of public services is to institutionalize a sound, transparent and responsive records management system in the office.

RA 9470 underscores that public records are essential to the administration and operation of all government offices, whether national or local, including GOCCs and government financial institutions (GFIs). Public records contain information which allows government programs to function, provide officials with a basis for making decisions and ensure continuity with past operations.

A compliant records management program is necessary for organizations to proactively and progressively manage all data, media and information. As the number of laws and severity of punishment governing records management continues to increase, it becomes even more paramount that organizations follow best practices for proper records management.

Anchored on the specific functions of records management, it can be perceived that inadequate knowledge and incompetence on records keeping could be detrimental to the interest of public administration; more on the affected individuals who are deprived of getting in touch of their own personal records which may have been utilized for important purposes. The security of records is likewise vital, so, certain policies and procedures had to be laid out to define and regulate the accessibility of the records or documents to the end users.

Appropriate interventions and output were formulated, based on the results of this study, to streamline the records management program of the public elementary and secondary schools in the Division of Mandaue City consistent with the provisions of Republic Act No. 9470, otherwise known as "The National Archives of the Philippines Act of 2007 and the guidelines depicted in the Records Management Operations Manual of the Department of Education (DepED).

\section{Related Literature}

Wallace (2001), stressed out that good archive and records management is of essential importance to the functioning of society, be it in business, law or public service. It creates greater accountability and transparency, and provides documentary evidence that establishes a tangible link to historic events by providing the raw material of our history and memory. For example, it is from ancient archives that we have gained insight into our ancestors and their civilizations. Archives and records management became critically significant in the 21 st century, known as the 
"information age" (also called the "computer age,") which spans from the advent of the personal computer in the 1970s through to the growth of the internet in the 1990s and the domination of rapid global technology at the turn of the century. In this context, archiving becomes a central part of the democratic process; it is fundamental to community, culture and personal identity. In a democratic society, archives underpin the citizens' rights and expectations of transparency.

Cox (2001) explained that since records are essential to any organization, questions challenging the record's definition are also crucial to the organization. The records management and archival literature portrays a record as relatively fixed, easily ascertained, and conveniently handled. One typical archives textbook defined record as "any type of recorded information, regardless of physical form or characteristics, created, received, or maintained by a person, institution, or organization.... Records are extensions of the human memory, purposefully created to record information, document transactions, communicate thoughts, substantiate claims, advance explanations, offer justifications, and provide lasting evidence of events. Their creation results from a fundamental human need to create and store information, to retrieve and transmit it, and to establish tangible connections with the past."

\section{Methodology}

\subsection{Research Methodology}

To attain the objectives of this study, the concept of descriptive survey method was utilized through a questionnaire to gather data coupled with actual interviews to supplement and validate the responses of the respondents. The research covered the present situation and prevailing activities involving records archiving practiced by the school records officers in the Division of Mandaue City; their respective profile which includes their age, civil status, years of experience as records in-charge, level of training-workshops and conferences attended, number of hours allotted for records keeping works during week days and the extent of their level of awareness on policies and guidelines introduced by the Department of Education and the provision of laws that govern records archiving.

\subsection{Research Instrument}

The population sample of this study was made of 96 respondents, 49 were the designated School Records Officers and 47 School Heads. Each one was made to answer competency-based questionnaire generated from the Department of Education Records Management Operations Manual and pertinent provisions of RA 9470.

The questionnaire covered two (2) parts. First part dealt with the profile and personal attributes of the respondents such as the level of training-workshops and seminars, age, civil status, years of experience as records officer and the number of hours devoted for records keeping works on week days by the respondents and other tasks performed by the respondents. The other part dealt with the level of awareness and implementation of the prescribed competencies and guidelines of the Department of Education Records Management Operations Manual the pertinent provisions of RA 9470. The competencies, guidelines and personal attributes were measured through 
appropriate statistical precepts. To ensure the veracity of the responses, the same were validated through actual interview with the respondents.

Validity refers to the data that are not only reliable but also true and accurate. In other words, it refers to the extent to which an instrument is able to actually assess what is supposed to measure, (Andales, 1992).

\section{Results and Discussion}

This Chapter portrays the Presentation, Analysis and Interpretation of the data taken from the responses of the respondents. Part I provides the profile of the respondents and Part II presents the extent of implementation and practices of the records management of the public schools in the Division of Mandaue City

\subsection{Profile of the Respondents}

The following tables portrayed the profile of the respondents as to their age, civil status, years of experience as designated school records officers, level of trainings, seminars and workshops attended, number of hours allotted for records keeping works during week days and other tasks performed in school.

Age

Table 1 depicted the distribution of the respondents' ages with their corresponding percentile.

Table 1: Distribution of the Respondents' Ages

\begin{tabular}{|l|l|l|l|l|}
\hline Particulars & School Head (f) & $\begin{array}{l}\text { Designated School } \\
\text { Records Officer (f) }\end{array}$ & Total (f) & Percentage \\
\hline 60 year. old up & 4 & 0 & 4 & 4.00 \\
\hline 50-59 years old & 12 & 6 & 18 & 19.00 \\
\hline 40-49 years old & 17 & 19 & 36 & 37.00 \\
\hline 30-39 years old & 9 & 16 & 25 & 26.00 \\
\hline 20-29 years old & 5 & 8 & 13 & 14.00 \\
\hline Total & 47 & 49 & 96 & 100 \\
\hline Mean Age & 43 years old & \multicolumn{2}{|l}{} \\
\hline
\end{tabular}

Table 1 showed that the bulk of age category ranged from 40 to 49 years old which covered 37.00 percent of the total number of respondents. It comprised 17 School Heads and 19 School Records Officers-designate. It was followed by $30-39$ years of age classification which garnered 26.00 percent with nine (9) School Heads and 16 School Records Officers-designate. The 50-59 years of age group emerged with 19.00 percent which was composed of 12 School Heads and six (6) School Records Officers-designate. While 14.00 percent went to 20-29 years old group with five (5) School Heads and eight (8) School Records Officers-designate, and only four (4.00) percent of the total population samples fell under 60 years old onward, attributed only to School Heads. 


\subsection{Years of Experience as School Records Officer-Designate/In-charge}

Table 2: Distribution of the Respondents' Years of Experience as Designated School Records Officer/In-Charge

\begin{tabular}{|l|l|l|l|l|}
\hline Particulars & School Head (f) & $\begin{array}{l}\text { Designated } \\
\text { School Records } \\
\text { Officer (f) }\end{array}$ & Total (f) & Percentage \\
\hline 13 years above & 7 & 6 & 13 & 14.00 \\
\hline $10-12$ years & 2 & 9 & 11 & 11.00 \\
\hline $7-9$ years & 11 & 6 & 17 & 18.00 \\
\hline $4-6$ years & 6 & 7 & 12 & 13.00 \\
\hline $1-3$ years & 7 & 21 & 28 & 29.00 \\
\hline Less a than year of experience & 14 & 0 & 14 & 15.00 \\
\hline Total & 47 & 49 & 96 & 100 \\
\hline Mean experience & 5 years & & \\
\hline
\end{tabular}

Table 2 revealed that 29.00 percent of the total samples had acquired $1-3$ years of experience as records officers in which seven (7) of whom were Schools Heads and 21 school records officersdesignate. The 7- 9 years group posted 18.00 percent of the samples with 11 school heads and six (6) records officers-designate. It was noted in the table that 14 school heads got less experience on records management, which covered 15.00 percent of the samples.

\subsection{Relevant Trainings, Seminars and Workshops Attended}

Table 3 showed the distribution of the respondents' relevant trainings, seminars and workshop attended. It also included the number of responses where the respondents had not gone through any of the trainings and seminars in all levels, respectively.

Table 3: Distribution of the Respondents' relevant Trainings, Seminars and Workshops Attended by School Records Officer-Designate

\begin{tabular}{|l|l|l|l|l|l|}
\hline \multirow{2}{*}{ Level } & \multicolumn{3}{|c|}{ School Records Officer-Designate } & Total (f) & Percentage \\
\cline { 2 - 5 } & $\begin{array}{c}\text { More than } \\
8 \text { hrs (f) }\end{array}$ & $\begin{array}{c}\text { More than } \\
\mathbf{2 4} \text { hrs (f) }\end{array}$ & $\begin{array}{c}\text { More than } \\
\mathbf{4 8} \text { hrs (f) }\end{array}$ & & \\
\hline National & 1 & 2 & 1 & 4 & 6.00 \\
\hline Regional & 1 & 3 & 1 & 5 & 8.00 \\
\hline Division & 14 & 2 & 3 & 19 & 31.00 \\
\hline $\begin{array}{l}\text { Has never attended in } \\
\text { any of the above }\end{array}$ & 16 & 10 & 8 & 34 & 55.00 \\
\hline TOTAL & 32 & 17 & 13 & 62 & 100.00 \\
\hline
\end{tabular}

(Multiple responses)

Table 3 exhibited the multiple responses on level of trainings, seminars and workshops attended by the designated school records officers relevant to records management which number of hours varied with each other. Collectively, only four (4) were able to attend in national level, five (5) 
had attended in the regional level and 19 in the division level. The said attendance garnered 6.00, 8.00 and 31.00 percent respectively, of the 62 total responses. However, 34 records officers, equivalent 55.00 percent of the total respondents, had never been gone to attend trainings in all levels, respectively. The bulk of trainings attended by the respondents were in the division and gained the largest part of the pie..

\subsection{Records Management System}

To attain and maintain standardized operation of a functional records office, the Department of Education has issued guidelines which are embodied in a manual to improve the delivery of records management services of the Department particularly the public schools. The manual contains written policies and standard operating procedures on all phases of records management functions namely: 1) the functions of the school records office, 2) duties and responsibilities of records officers, and 3) procedures in handling communications, legal documents and administrative issuance; classifying records, access to official files and personal information, records disposal and period of retention of records and documents. Each component suggests guidelines of activities and competencies to be undertaken to satisfy a sound and effective records management system in the office.

\subsection{Functions of the School Records Office}

Presented in the following table were the desired functions of the records offices of public schools in the Division stipulated in the manual as perceived by the two (2) respondent groups composed of 47 school heads and 49 teachers designated as school records officers.

Table 4: Functions of the Records Offices of Public Schools in Mandaue City Division during the School Year 2012-2013 as perceived by the School Heads and Designated School Records

Officers

\begin{tabular}{|c|c|c|c|c|}
\hline $\begin{array}{l}\text { Functions of the } \\
\text { Records Office }\end{array}$ & $\begin{array}{l}\text { Weighted Mean } \\
\text { (School Heads) }\end{array}$ & Interpretation & $\begin{array}{c}\text { Weighted Mean } \\
\text { (School Records } \\
\text { Officers) }\end{array}$ & Interpretation \\
\hline $\begin{array}{l}\text { 1. Establishes and } \\
\text { maintains a systematic } \\
\text { records system for the } \\
\text { school in an orderly, } \\
\text { efficient, effective and } \\
\text { economical manner. }\end{array}$ & 3.60 & $\begin{array}{c}\text { Well } \\
\text { Implemented }\end{array}$ & 3.36 & Implemented \\
\hline $\begin{array}{l}\text { 2. Implements the } \\
\text { records management } \\
\text { program, its policies and } \\
\text { procedures in the } \\
\text { creation, maintenance, } \\
\text { use and disposition of } \\
\text { records. }\end{array}$ & 3.60 & $\begin{array}{c}\text { Well } \\
\text { Implemented }\end{array}$ & 3.36 & Implemented \\
\hline $\begin{array}{l}\text { 3. Receives, releases } \\
\text { mail: disseminates and } \\
\text { distributes all official }\end{array}$ & 3.70 & $\begin{array}{c}\text { Well } \\
\text { Implemented }\end{array}$ & 3.21 & Implemented \\
\hline
\end{tabular}




\begin{tabular}{|c|c|c|c|c|c|c|c|}
\hline \multicolumn{3}{|c|}{$\begin{array}{l}\text { communication and } \\
\text { correspondence with } \\
\text { prompt dispatch to the } \\
\text { field and concerned } \\
\text { offices. }\end{array}$} & & & & & \\
\hline \multicolumn{3}{|c|}{$\begin{array}{l}\text { 4. Disposes old files that } \\
\text { have reached their } \\
\text { retention period in } \\
\text { accordance with the } \\
\text { existing rules, regulations } \\
\text { and laws (RA 9470) }\end{array}$} & & 3.30 & Implemented & 1.16 & $\begin{array}{c}\text { Least } \\
\text { Implemented }\end{array}$ \\
\hline \multicolumn{3}{|c|}{$\begin{array}{l}\text { 5. Monitors and } \\
\text { evaluates the records } \\
\text { management } \\
\text { program. }\end{array}$} & & 3.20 & Implemented & 3.19 & Implemented \\
\hline \multicolumn{3}{|c|}{ Average Mean } & & 3.50 & $\begin{array}{l}\text { Well } \\
\text { Implemented } \\
\text { (More than } \\
85 \% \text { but less } \\
\text { than } 100 \% \\
\text { adherence to } \\
\text { the existing } \\
\text { guidelines) }\end{array}$ & 2.85 & $\begin{array}{l}\text { Implemented } \\
\text { (More than } \\
50 \% \text { but less } \\
\text { than } 85 \% \\
\text { adherence to } \\
\text { the existing } \\
\text { guidelines) }\end{array}$ \\
\hline Legend: & $\begin{array}{l}4.20 \\
3.40 \\
2.60 \\
1.80 \\
1.00\end{array}$ & $\begin{array}{l}- \\
- \\
- \\
-\end{array}$ & $\begin{array}{l}5.00 \\
4.19 \\
3.39 \\
2.59 \\
1.79\end{array}$ & \multicolumn{3}{|c|}{$\begin{array}{l}\text { Very well-implemented (VW) } \\
\text { Well Implemented (WI) } \\
\text { Implemented (I) } \\
\text { Poorly Implemented (PI) } \\
\text { Least/ Not Implemented (LI) }\end{array}$} & \\
\hline
\end{tabular}

Shown in Table 4 were the functions of the records offices of public schools in the Division of Mandaue City during the School Year 2012-2013, as perceived by the and school heads and teachers designated as school records officers, in relation to the mandated guidelines of the Department of Education for records management operations. The table showed that three (3) guidelines were religiously well-implemented by the School Heads to wit: a) establishes and maintains a systematic records system for the school in an orderly, efficient, effective and economical manner which gained a mean of $3.60, \mathrm{~b}$ ) implements the records management program, its policies and procedures in the creation, maintenance, use and disposition of records which obtained a mean of 3.60, and c) receives, releases mail: disseminates and distributes all official communication and correspondence with prompt dispatch to the field and concerned offices which claimed a mean of 3.70 .

\subsection{Duties and Responsibilities of School Records Officer}

The table below portrayed the extent of demonstration by the 47 School Heads and 49 respondent teachers designated as school Records Officers in the context of the department's recommended duties and responsibilities for School Records Officers. 
Table 5: Extent of Implementation of the Duties and Responsibilities of School Records Officers in Mandaue City Division during the School Year 2012-2013 as perceived by the Designated School Records Officers and School Heads

\begin{tabular}{|c|c|c|c|c|}
\hline Duties and Responsibilities & $\begin{array}{l}\text { Weighted Mean } \\
\text { (School Heads) }\end{array}$ & Interpretation & $\begin{array}{c}\text { Weighted Mean } \\
\text { (School Records } \\
\text { Officers) }\end{array}$ & Interpretation \\
\hline $\begin{array}{l}\text { 1. Plans, directs and } \\
\text { supervises clerical task } \\
\text { such as receiving, } \\
\text { processing and routing of } \\
\text { incoming and out going } \\
\text { correspondence or } \\
\text { communication and } \\
\text { reports for submission to } \\
\text { the District } \\
\text { Office/Division Office/ in } \\
\text { any office. }\end{array}$ & 3.68 & $\begin{array}{c}\text { Well } \\
\text { Implemented }\end{array}$ & 3.56 & $\begin{array}{c}\text { Well } \\
\text { implemented }\end{array}$ \\
\hline $\begin{array}{l}\text { 2. Assumes responsibility } \\
\text { for the custody and } \\
\text { safekeeping of official } \\
\text { records and documents }\end{array}$ & 3.86 & $\begin{array}{c}\text { Well } \\
\text { Implemented }\end{array}$ & 3.94 & $\begin{array}{c}\text { Well } \\
\text { implemented }\end{array}$ \\
\hline $\begin{array}{l}\text { 3. Establishes and } \\
\text { maintains an actual } \\
\text { continuing program for } \\
\text { the management, } \\
\text { preservation and } \\
\text { disposition of records. }\end{array}$ & 3.91 & $\begin{array}{c}\text { Well } \\
\text { Implemented }\end{array}$ & 3.41 & $\begin{array}{c}\text { Well } \\
\text { Implemented }\end{array}$ \\
\hline $\begin{array}{l}\text { 4. Determines the unit's } \\
\text { supplies and equipment } \\
\text { needs. }\end{array}$ & 3.23 & Implemented & 3.62 & $\begin{array}{c}\text { Well } \\
\text { Implemented }\end{array}$ \\
\hline $\begin{array}{l}\text { 5. Assigns work, issues } \\
\text { verbal or written } \\
\text { instructions and reviews } \\
\text { accomplished works for } \\
\text { accuracy and conformity } \\
\text { with the standing policies } \\
\text { and procedures. }\end{array}$ & 3.82 & $\begin{array}{c}\text { Well } \\
\text { Implemented }\end{array}$ & 3.43 & $\begin{array}{c}\text { Well } \\
\text { Implemented }\end{array}$ \\
\hline $\begin{array}{l}\text { 6. Maintains } \\
\text { students'/pupils' personal } \\
\text { and scholastic records and } \\
\text { related documents. }\end{array}$ & 4.55 & $\begin{array}{c}\text { Very Well } \\
\text { Implemented }\end{array}$ & 4.05 & $\begin{array}{c}\text { Well } \\
\text { Implemented }\end{array}$ \\
\hline $\begin{array}{l}\text { 7. Maintains school } \\
\text { personnel and officials' } \\
\text { employment records and } \\
\text { related documents. }\end{array}$ & 4.50 & $\begin{array}{c}\text { Very Well } \\
\text { Implemented }\end{array}$ & 3.67 & $\begin{array}{c}\text { Well } \\
\text { Implemented }\end{array}$ \\
\hline 8. Maintains school vital & 4.86 & Very Well & 3.43 & Well \\
\hline
\end{tabular}




\begin{tabular}{|c|c|c|c|c|}
\hline $\begin{array}{l}\text { records and documents } \\
\text { such as deed of donations, } \\
\text { school site title, tax } \\
\text { Declaration and other } \\
\text { documents related to the } \\
\text { construction of the school } \\
\text { building and acquisition } \\
\text { of school site. }\end{array}$ & & Implemented & & Implemented \\
\hline $\begin{array}{l}\text { 9. Maintains back up } \\
\text { files (duplicate or soft } \\
\text { copies) of all the vital } \\
\text { documents stored in the } \\
\text { records office. }\end{array}$ & 3.64 & $\begin{array}{c}\text { Well } \\
\text { Implemented }\end{array}$ & 3.26 & Implemented \\
\hline $\begin{array}{l}\text { 10. Establishes and } \\
\text { observes safety measures } \\
\text { in documents and records } \\
\text { archiving. }\end{array}$ & 3.95 & $\begin{array}{c}\text { Well } \\
\text { Implemented }\end{array}$ & 3.49 & $\begin{array}{c}\text { Well } \\
\text { Implemented }\end{array}$ \\
\hline $\begin{array}{l}\text { 11. Observes protocol in } \\
\text { handling sensitive } \\
\text { communications. }\end{array}$ & 4.00 & $\begin{array}{c}\text { Well } \\
\text { Implemented }\end{array}$ & 3.87 & $\begin{array}{c}\text { Well } \\
\text { Implemented }\end{array}$ \\
\hline $\begin{array}{l}\text { 12. Authenticates copies } \\
\text { of documents. }\end{array}$ & 4.09 & $\begin{array}{c}\text { Well } \\
\text { Implemented }\end{array}$ & 3.61 & $\begin{array}{c}\text { Well } \\
\text { Implemented }\end{array}$ \\
\hline Average Mean & 4.01 & $\begin{array}{c}\text { Well } \\
\text { Implemented } \\
(85 \% \\
\text { adherence to } \\
\text { the } \\
\text { guidelines) }\end{array}$ & 3.61 & $\begin{array}{c}\text { Well } \\
\text { Implemented } \\
\text { (85\% } \\
\text { adherence to } \\
\text { the } \\
\text { guidelines) }\end{array}$ \\
\hline $\begin{array}{l}4.20-5.00 \\
2.60-3.39 \\
1.00-1.79 \\
3.40-4.19 \\
1.80-2.59\end{array}$ & $\begin{array}{l}\text { Very well } \\
\text { Implemen } \\
\text { Least/ No } \\
\text { Well Impl } \\
\text { Poorly Im }\end{array}$ & $\begin{array}{l}\text { nented }(\mathrm{VW}) \\
\text { nented }(\mathrm{LI}) \\
\mathrm{d}(\mathrm{WI}) \\
\text { ted }(\mathrm{PI})\end{array}$ & & \\
\hline
\end{tabular}

Described in Table 5 were the perceptions of the School Heads and School Records Officers on the level of the implementation of the mandated "duties and responsibilities of school records officers". The table showed that there were three (3) guidelines of which the School Heads, by their own assessment, had very well implemented in their schools. These were items numbers 6 , 7, and 8. Item six (6) required the records officer to maintain students'/pupils' personal and scholastic records and other related documents. Item seven (7) mandated the records officer to maintain school personnel and officials' employment records and other related documents. The last was item (8) which called for proper maintenance of school vital records and documents such as deed of donations, school site title, tax Declaration and other documents related to the construction of the school building and acquisition of school site. Each of them had registered a weighted mean of $4.55,4.50$ and 4.86 , respectively. 


\subsection{Procedures for School Records Management Operations}

Table 6 depicted the mean responses of the respondents on the procedure for school records management operations. May it be noted that there were 13 elements of procedure to be observed by the school records officers as mandated in the manual. Each element had its own set of competencies for the respondents to satisfy. Their mean responses were collated and tabulated as shown in the table.

Table 6: School Records Management Operation of Public Schools in Mandaue City Division on the School Year 2012-2013 as perceived by the School Heads and the Designated School Records Officers

\begin{tabular}{|c|c|c|c|c|}
\hline $\begin{array}{l}\text { Records Management } \\
\text { Operation }\end{array}$ & $\begin{array}{c}\text { Weighted } \\
\text { Mean } \\
\text { (School Heads) }\end{array}$ & Interpretation & $\begin{array}{c}\text { Weighted Mean } \\
\text { (School Records } \\
\text { Officers) }\end{array}$ & Interpretation \\
\hline $\begin{array}{l}\text { 1. handling incoming } \\
\text { mail/communications }\end{array}$ & 3.08 & Implemented & 2.52 & $\begin{array}{c}\text { Poorly } \\
\text { Implemented }\end{array}$ \\
\hline $\begin{array}{l}\text { 2. handling outgoing } \\
\text { mail/communications }\end{array}$ & 2.97 & Implemented & 2.48 & $\begin{array}{c}\text { Poorly } \\
\text { Implemented }\end{array}$ \\
\hline $\begin{array}{l}\text { 3. handling incoming legal } \\
\text { documents }\end{array}$ & 2.79 & Implemented & 2.40 & $\begin{array}{c}\text { Poorly } \\
\text { Implemented }\end{array}$ \\
\hline $\begin{array}{l}\text { 4. handling outgoing legal } \\
\text { documents }\end{array}$ & 2.75 & Implemented & 2.57 & $\begin{array}{c}\text { Poorly } \\
\text { Implemented }\end{array}$ \\
\hline $\begin{array}{l}\text { 5. handling administrative } \\
\text { issuances }\end{array}$ & 3.11 & Implemented & 2.87 & Implemented \\
\hline $\begin{array}{l}\text { 6. classification guide for } \\
\text { filing school management } \\
\text { documents }\end{array}$ & 3.09 & Implemented & 2.69 & Implemented \\
\hline 7. procedure for filing & 2.74 & Implemented & 2.26 & $\begin{array}{c}\text { Poorly } \\
\text { Implemented }\end{array}$ \\
\hline 8. services with files & 2.45 & $\begin{array}{c}\text { Poorly } \\
\text { Implemented }\end{array}$ & 2.36 & $\begin{array}{c}\text { Poorly } \\
\text { Implemented }\end{array}$ \\
\hline $\begin{array}{l}\text { 9. request for personal } \\
\text { information }\end{array}$ & 3.07 & Implemented & 3.01 & Implemented \\
\hline 10. access to files & 3.10 & Implemented & 2.87 & Implemented \\
\hline $\begin{array}{l}\text { 11. records disposal } \\
\text { procedure }\end{array}$ & 2.12 & $\begin{array}{c}\text { Poorly } \\
\text { Implemented }\end{array}$ & 1.02 & $\begin{array}{c}\text { Least } \\
\text { Implemented }\end{array}$ \\
\hline 12. preservation of records & 3.02 & Implemented & 1.68 & $\begin{array}{c}\text { Least } \\
\text { Implemented }\end{array}$ \\
\hline $\begin{array}{l}\text { 13. retention period of } \\
\text { records/documents }\end{array}$ & 3.14 & Implemented & 1.94 & $\begin{array}{c}\text { Poorly } \\
\text { Implemented }\end{array}$ \\
\hline Average Mean & 2.88 & $\begin{array}{l}\text { Implemented } \\
\text { ( more than } \\
50 \% \text { but not } \\
\text { more than } 85 \% \\
\text { adherence to } \\
\text { the guidelines) }\end{array}$ & 2.36 & $\begin{array}{c}\text { Poorly } \\
\text { Implemented } \\
\text { ( } 50 \% \\
\text { adherence to } \\
\text { the existing } \\
\text { guidelines) }\end{array}$ \\
\hline
\end{tabular}


Legend: $\quad 4.20-5.00 \quad$ Very well-implemented (VW)

2.60 - 3.39 Implemented ( I)

$1.00-1.79$ Least/ Not Implemented (LI)

3.40 - 4.19 Well Implemented (WI)

$1.80-2.59$ Poorly Implemented (PI

Portrayed in Table 6 was the status of the School Records Management Operations of public schools in Mandaue City Division during the school year 2012-2013 as perceived by the school heads and designated school records officers. For the perceptions of the School Heads, it was noted that 11 out of 13 components fell within the range of $2.60-3.39$, which can be construed that less than $85 \%$ of the guidelines, as perceived by the School Heads, were satisfactorily implemented in their schools. Among those were: Item one (1), which registered a mean of 3.08, defined the procedure on how to handle incoming mails and communications; guideline two (2) introduced the procedure in handling outgoing mails and communications; numbers three (3) and four (4) described the procedure in handling incoming and outgoing legal documents poured out their means of 2.79 and 2.75, respectively. Another component which defined proper course of action was handling administrative issuances. It registered a mean of 3.11. Item six (6) got a mean of 3.09. It introduced classification guides for filing school management documents. Item seven (7) provided guidelines for filing got a mean of 2.74. Items nine (9) and ten (10) provided restrictions as to who shall be allowed to get access to official files in school and personal information of students/pupils and school officials. The duo registered means of 3.07 and 3.10, respectively. The last two (2) components provided guidelines on prevention of records and documents and their retention period. Item 12 claimed a mean of 3.02 while item 13 enjoyed a mean of 3.14 .

\subsection{Mean Difference of the Respondent Groups' Perceptions anent the Prescribed Aspects of School Records Management}

Presented in Table 7 were the results that satisfied the Null Hypothesis of this study which tended to look into the mean difference of the respondent groups' perceptions anent the prescribed aspects of records management in school. This study statistically employed the concept of $\boldsymbol{t}$-test in testing the significance of the difference between means of the responses of the two respondent groups.

Table 7: Mean Difference of the Respondent Groups' Perceptions on the Components of Records Management

\begin{tabular}{|c|c|c|c|c|}
\hline $\begin{array}{c}\text { Component of Records } \\
\text { Management }\end{array}$ & $\begin{array}{l}\text { Tabled " } t \text { " value } \\
\text { at } 0.05 \text { level of } \\
\text { significance }\end{array}$ & $\begin{array}{l}\text { Computed } \\
\text { "tt" value }\end{array}$ & Decision & Remarks \\
\hline 1. Functions of Records Office & 2.26 & 1.94 & $\begin{array}{c}\text { Accept } \\
\mathrm{H}_{\mathrm{O}}\end{array}$ & $\begin{array}{c}\text { Not } \\
\text { Significant } \\
\end{array}$ \\
\hline $\begin{array}{l}\text { 2. Duties and Responsibilities } \\
\text { of Records Officers }\end{array}$ & 2.07 & 0.61 & $\begin{array}{c}\text { Accept } \\
\mathrm{H}_{\mathrm{O}}\end{array}$ & $\begin{array}{c}\text { Not } \\
\text { Significant }\end{array}$ \\
\hline $\begin{array}{l}\text { 3. Operating Procedures of } \\
\text { Records Management System }\end{array}$ & 2.07 & 3.94 & $\begin{array}{c}\text { Reject } \\
\mathrm{H}_{\mathrm{O}}\end{array}$ & Significant \\
\hline
\end{tabular}


Table 7 indicated the statistical computation of values which explained the significant difference of two (2) means from the perceptions of the respondent groups in every aspect of Records Management. In the first component, the Functions of Records Office, at 0.05 level of significance the tabled value was 2.26. Upon computation of the " $t$ " ratio, the result yielded a value of 1.94 lower than the tabled value. Comparing the tabled value and the computed one, it can be perceived that the null hypothesis was then accepted, which means that "'there has been no significant mean difference among the respondent groups' perception on the aforementioned prescribed aspects of the School Records Management System '”.

\section{Conclusion}

As generally disclosed in the findings of this study, the respondents have satisfactorily observed the competencies of the two (2) prescribed aspects of Records Management, however, they demonstrated incompetence in the implementation of the competencies prescribed in the procedure of operations of Records Management. Indeed, a significant mean difference is evident on their perceptions, as it is scientifically determined through the aid of a generally accepted statistical method, anent the implementation of the prescribed aspects of Records Management.

The incompetence exhibited by the respondents on the concept of procedural operations of records management will adversely affect the fundamental responsibilities of the school to the students or pupils, teachers and other school personnel, parents, stakeholders and the entire community, as well. More, that the school mission and vision in consonance to the Education for For All (EFA) goals will be futile.

The responses between the first two aspects and the third one may have been construed as inconsistent. A thorough analysis was employed on the results and found out the competencies for the first two aspects were general in nature and that a number of respondents, in their own perceptions only, were consciously aware of the competencies but practically failed to impressively implement the competencies of the third aspect which defined the specific guidelines in the operating procedure of school records management. Indeed, the respondents may have been aware of their duties and functions as records officers or custodians but failed to implement the appropriately the procedure of operations in Records Management.

\section{References}

[1] Cox, R.J. and Wallace, D.A. (2002) Archives and The Public Good: Accountability and Records In Modern Society, Westport, CT, Quorom Books.

[2] Sampson, K. (1992) Value-Addedd Records Management, Quorom Books.

*Corresponding author.

E-mail address: villaganas@ gmail.com 